\title{
Analysis of the agricultural productivity of the sugarcane crop in regions of new agricultural expansions of sugarcane
}

\section{GESTÃO PRODỨCÃO}

ISSN 0104-530X (Print) ISSN 1806-9649 (Online)

\section{Análise da produtividade agrícola da cultura da cana-de-açúcar em regiões de novas expansões agrícolas canavieiras}

\author{
Roberto Bernardo' 1 (1) \\ Wagner Luiz Lourenzani ${ }^{2}$ (]) \\ Eduardo Guilherme Satolo ${ }^{2}$ (1) \\ Marcellus Marques Caldas ${ }^{3}$ (i)
}

How to cite: Bernardo, R., Lourenzani, W. L., Satolo, E. G., \& Caldas, M. M. (2019). Analysis of the agricultural productivity of the sugarcane crop in regions of new agricultural expansions of sugarcane. Gestão \& Produção, 26(3), e3554. https://doi.org/10.1590/0104-530X3554-19

\begin{abstract}
The launching of biofuel vehicles in 2003 led to ethanol demand increase and a new phase of expansion of sugarcane cultivation in Brazil. Although the increase in area of production and the quantity of sugarcane produced have been very important to Brazilian agribusiness, the recent agricultural productivity rate has slowed. In this context, this article analyzed the factors that influence the growth rate of sugarcane productivity in the regions of new agricultural expansions, specifically in the states of Mato Grosso do Sul and Goias. For the collection and data analysis, we used bibliographical and documentary research. The shift-share method was used to analyze the evolution of sugarcane production, through the decomposition of this variable into two factors: area effect and productivity effect. The results show that the increase in production in the region under analysis was mainly due to the incorporation of new planting areas and not to an increase in productivity. In addition, structural factors have negatively impacted crop performance. The analysis indicates that there is a slow rhythm of sugarcane fields' renovation and the adoption of old varieties. Although the mechanization index is high in the studied regions, difficulties of technological adaptation still provide deficiency in the agricultural performance of sugarcane.
\end{abstract}

Keywords: Sugar and alcohol industry; Agricultural mechanization; Shift-share.

Resumo: O lançamento dos veículos bicombustiveis, no ano de 2003, propiciou a retomada da importância da produção de etanol e, consequentemente, numa nova fase de expansão do cultivo de cana-de-açúcar no Brasil. Embora o aumento da área de produção e da quantidade produzida de cana-de-açúcar mereça destaque no agronegócio brasileiro, o mesmo não se pode considerar para a sua produtividade agrícola recente. Nesse contexto, esse artigo analisou os fatores que influenciam o ritmo de crescimento da produtividade da cana-de-açúcar, nas regiões de novas expansões agrícolas canavieiras, especificamente, nos estados de Mato Grosso do Sul e de Goiás. Para a coleta e análise dos dados foram utilizadas a pesquisa bibliográfica e a documental. O método Shift-Share foi utilizado para analisar a evolução da produção de cana-de-açúcar, por meio da decomposição dessa variável em dois fatores, efeito área e efeito produtividade. Os resultados demonstram que o aumento da produção, na região em análise, deveu-se predominantemente à incorporação de novas áreas de plantio e não por incremento na produtividade. Além disso, fatores estruturais têm impactado negativamente no desempenho da cultura. As análises indicam que há um ritmo lento de renovação dos canaviais, com a adoção de variedades antigas. Embora o índice de mecanização nas regiões em estudo seja alto, dificuldades de adaptação tecnológica ainda proporcionam deficiências no desempenho agrícola canavieiro.

Palavras-chave: Setor sucroalcooleiro; Mecanização agrícola; Shift-share.

${ }^{1}$ Programa de Pós-graduação em Engenharia de Produção, Universidade Federal de São Carlos - UFSCar, Alameda Manchester, 390, CEP 17603-660, Tupã, SP, Brasil, e-mail: ch.bernardo@uol.com.br

${ }^{2}$ Programa de Pós-graduação em Agronegócio e Desenvolvimento, Universidade Estadual Paulista - UNESP, Av. Domingos da Costa Lopes, 780, CEP 17602-496, Tupã, SP, Brasil, e-mail: wagner@tupa.unesp.br; eduardo@tupa.unesp.br

${ }^{3}$ Department of Geography, Kansas State University - KSU, 118 Seaton Hall, 66506, Manhattan, KS, United States of America, e-mail: caldasma@ksu.edu 


\section{Introduction}

The Central-West region of Brazil has recently faced a significant process of sugarcane area expansion. According to Castro et al. (2010), this process was driven by the advance of the sugar-energy sector, in order to meet the demand for sugar production and, especially, the vigorous demand for ethanol, both in the domestic and international markets.

Between 2003 and 2014, both harvested area and sugar cane production doubled in the country (IBGE, 2015), triggering changes in the representativeness of the Brazilian producing regions. The expansion process mentioned above has placed the Central-West as the second largest producer region of the country, as well as being the region with the greatest expansion in an area intended for planting (Demattê et al., 2014). Mato Grosso do Sul and Goias were the states that stood out the most, with a growth rate of $431 \%$ and $425 \%$, respectively, of planted area (ha) between 2003 and 2014 (IBGE, 2015).

The promising prospect of widespread sugarcane crop growth in the country, and in the Central-West region, faces some bottlenecks that need to be explored and analyzed in order to be overcome. Although there has been a significant increase in the quantity of sugarcane produced in the studied region, the reduced influence of the productivity factor in this process deserves to be explored and analyzed.

According to Santos (2016) and Furtado et al. (2011), in the last four decades the sugarcane crop has made significant progress in Brazil, and is currently a world reference in technologies for production and processing. In order to increase the competitiveness of the production system, the national technologies allowed for prolonging the life of sucarcane plantations, as well as using inputs and labor more efficiently (Oliveira et al., 2012). Despite the above mentioned progress, sugarcane productivity has in recent years presented a distinct trajectory, with years of reduced indicator indicators, although the long-term analysis reveals that the path continues to grow (Nyko et al., 2013).

Still according to Nyko et al. (2013), the factors responsible for the downward trend in productivity indices in sugarcane cultivation in Brazil can be classified as conjunctural and structural. The conjunctural factors are those associated to short-term oscillations of performance, such as climatic adversities, lack of adequate sugarcane renovation, sugarcane aging and reduced crop investment (Neves, 2012; Demattê, 2012). On the other hand, the structural factors are those related to long-term performance and, in the case of sugarcane, Nyko et al. (2013) suggest that the main constraints have been the mechanization of planting and harvesting and the adoption of inadequate sugarcane varieties.
Considering that the recent sugarcane expansion in regions of agricultural frontier occurred through a modern productive system, in a context of access to technology coming from a wide research trajectory, the performance of sugarcane is an important issue to be scientifically analyzed.

In this context, this article aims to analyze the agricultural productivity of the sugarcane crop in recent areas of expansion; especially in the states of Mato Grosso do Sul and Goias. Specifically, we intended to: a) understand the influence of the factors "area" and "productivity" on the evolution of sugarcane crop in these states, and b) verify how the structural factors - index of mechanization and the use of adequate varieties - have affected the productivity of sugarcane in the states under analysis.

In order to achieve the proposed goals, this article is structured in five parts. The first one, already presented, contextualizes and justifies the relevance of the work, as well as establishes its objective. The second part gives a brief review of the literature on the expansion of sugarcane cultivation in regions of new agricultural expansions. The third part shows the methodological procedure used. The results and discussions are discussed in part four. Finally, the conclusions of the paper are presented.

\section{Expansion of sugarcane culture in regions of new agricultural expansions}

The interest of the countries in cleaner solutions for the transport sector and the launching of flex fuel vehicles motivated the increase of ethanol production, and consequently, promoted a new phase of expansion of the crop in Brazil (Spera et al., 2017; Lourenzani \& Caldas, 2014; Camargo et al., 2008). According to the authors, the growth of the area destined to sugarcane, industrial plants and the construction of new plants were the result of decisions of the private initiative and strongly stimulated by public policies.

Between 2003 and 2014, both harvested area and sugar cane production practically doubled in the country. During this period, about 5 million hectares were added, with an increase in production of approximately 340 million tons (IBGE, 2015). This process triggered changes in the representativeness of Brazilian producer regions (Castro et al., 2010). Figure 1 shows the share of sugarcane in Brazil, by region, between 1990 and 2014 .

The data show that Southeast region prevails in the country. However, from 2008 on, the Central-West region assumes the second position, overtaking the Northeast region, historically, a traditional region of sugarcane cultivation. This dynamic shows that the Central-West region is a new agricultural frontier for sugarcane cultivation, representing $18 \%$ share 
of national production in 2014, with a clear trend of growth.

According to Abdala \& Ribeiro (2011) and Castro et al. (2010), the Cerrado biome attracts investments of sugar-alcohol enterprises, due to its edaphoclimatic conditions, very similar to that of the Western region of São Paulo State, traditional sugarcane cultivation area, and because the biome is located within in the Agro-Ecological Zoning of Sugarcane (ZAE Cana) (Established by the Brazilian government, the Agro-Ecological Zoning of Sugarcane maps areas suitable for the production of sugarcane, based on edaphoclimatic conditions, as well as environmental, social and economic aspects). According to Granco et al. (2017) and Domingues \& Thomaz (2012), some other factors were determinant for the agroindustry to invest in the region, such as land lower acquisition and lease values, when compared to São Paulo; fiscal incentives in the region; proximity to important consumer centers; facilitated rural credit; the support of agricultural technology research institutes; the development of agricultural mechanization; as well as low conflicts involving social movements over agrarian issues.

The period from 2003 to 2014 presented an expansion of the planted area of sugarcane of $95 \%$ in Brazil; in the states of Mato Grosso do Sul and Goias this index was, respectively, $431 \%$ and $425 \%$ (IBGE, 2015) (Table 1).

Therefore, a large part of the expansion of the sugarcane planted area in the country between 2003 and 2014 occurred in these two states of the Central-West of Brazil: the state of Mato Grosso do Sul represented 54\% (2.75 million hectares), and Goias 13\% (0.65 million hectares) (IBGE, 2015). From Figure 2, it can be verified that the inflections of

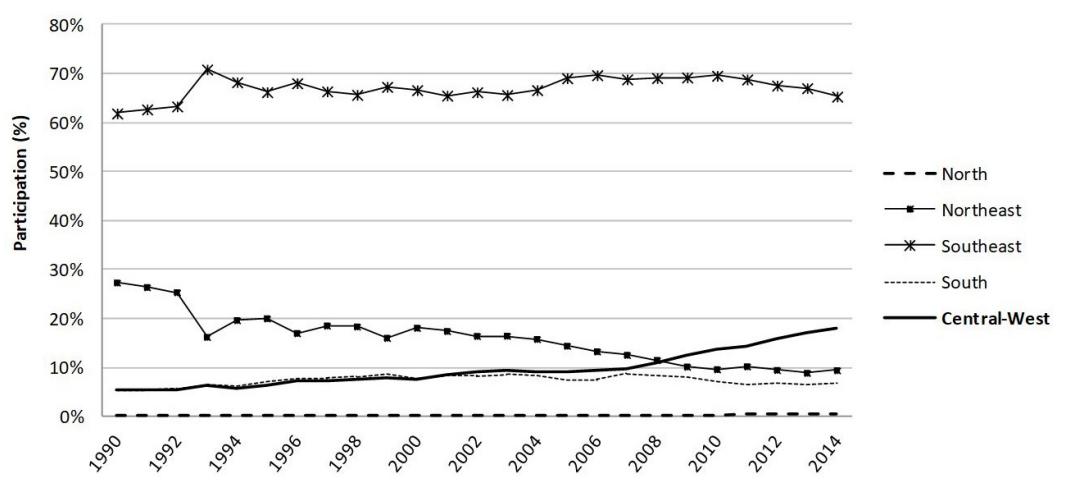

Figure 1. Participation (\%) of sugarcane quantity in Brazil, by region, between 1990 and 2014. Source: The authors, based on IBGE (2015).

Table 1. Evolution (\%) of the sugarcane planted area in Brazil and main states, between 2003 and 2014.

\begin{tabular}{ccccccccc}
\hline Brazil & $\begin{array}{c}\text { Mato } \\
\text { Grosso do } \\
\text { Sul }\end{array}$ & Goias & $\begin{array}{c}\text { Minas } \\
\text { Gerais }\end{array}$ & Sao Paulo & Parana & $\begin{array}{c}\text { Mato } \\
\text { Grosso }\end{array}$ & Alagoas & Pernambuco \\
\hline $95 \%$ & $\mathbf{4 3 1 \%}$ & $\mathbf{4 2 5 \%}$ & $213 \%$ & $98 \%$ & $82 \%$ & $44 \%$ & $8 \%$ & $-15 \%$ \\
\hline
\end{tabular}

Source: The authors, based on IBGE (2015).

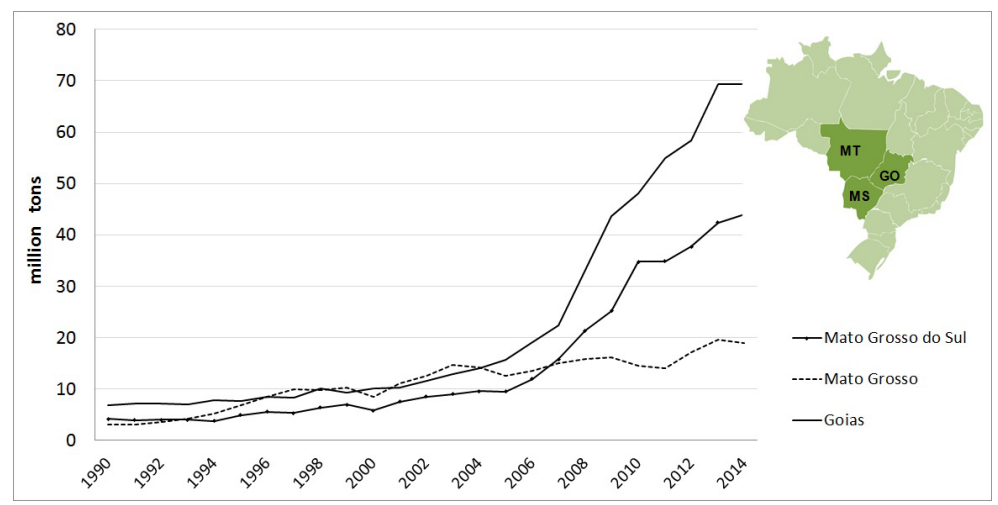

Figure 2. Evolution of the amount of sugarcane produced (million tons) in the states of Central-West Brazil, in the period between 1990 and 2014. Source: The authors, based on IBGE (2015). 
the sugarcane production lines of Goias was in 2004 and Mato Grosso do Sul was in 2005. This period coincides with the increase of ethanol demand due to the development of flex-fuel cars (Castro et al., 2010).

This process of strong expansion leads to complex and multidimensional transformations in the regions. Several scientific debates have been related to the sustainability of bioenergy production, with emphasis on environmental, social, and food production and food security impacts (Gilio \& Moraes, 2016; Lourenzani \& Caldas, 2014).

According to Demattê (2012) and Nyko et al. (2013), the intensive expansion of sugarcane activity was predominantly due to the incorporation of areas and very little to productivity gains. The authors argue that conjunctural (short term) and structural (long term) factors are responsible for the downward trend in productivity of this activity in Brazil. When comparing the historical performance of the sugarcane crop with other important Brazilian agricultural crops, such as corn and soybeans, in the period between 1990 and 2014 (IBGE, 2015), it is observed that, in addition to presenting much lower productivity gains, the sugarcane agricultural performance shows a downward trend in recent years (Figure 3).

According to Nyko et al. (2013), the above expected performance of sugarcane in relation to other crops highlights the classic problem of the discrepancy between private and social investment in research and development (R\&D). According to the authors, although the sugar-energy sector is very important for Brazil, as a source of energy supply and foreign exchange, its size is relatively small in the world, not generating economic attractiveness for more expensive and risky R\&D investments. The challenges of incorporating technology, the low dynamism and inconsistencies in the productive environment, have prevented the increase of sugarcane agricultural productivity (Santos, 2016).

\section{Material and methods}

The methodological basis adopted in this study has an exploratory approach and is based on a qualitative-quantitative research. The qualitative research based both the review on the sugarcane expansion in the new regions of sugarcane expansion and the specific objective of verifying how the structural factors affect sugarcane productivity in the states analyzed. The quantitative research was important to answer the other specific objective, which was to understand the influence of explanatory factors (area and productivity) on the evolution of sugarcane production in these states.

In the qualitative approach, bibliographical and documentary research were used. In order to collect data, Brazilian Institute of Geography and Statistics (as its acronym in Portuguese - IBGE) provided the official statistical data by means of its Automatic Recovery System - SIDRA (IBGE, 2015). The temporal cut of the data is relative to the period from 2003 to 2014, due to the acknowledged new phase of expansion of sugarcane cultivation in Brazil. The choice of the quantitative method of analysis was based on the review of different scientific papers that deal with the topic. In the same way, several scientific works were selected and used to subsidize the discussion of the results obtained.

For the quantitative analysis, this research adopted the Shift-Share model, also known as "Differential-Structural" model. According to Pereira (1997), this model is appropriate to understand the growth of a region or a product in a given condition. According to Abdala \& Ribeiro (2011), several authors have analyzed agricultural development, using a formal shift-share method, identifying sources of growth, performance and indicators of agricultural modernization. Similar studies were adopted by Camara \& Caldarelli (2016), Lourenzani \& Caldas (2014), Abdala \& Ribeiro (2011) and Camargo et al.

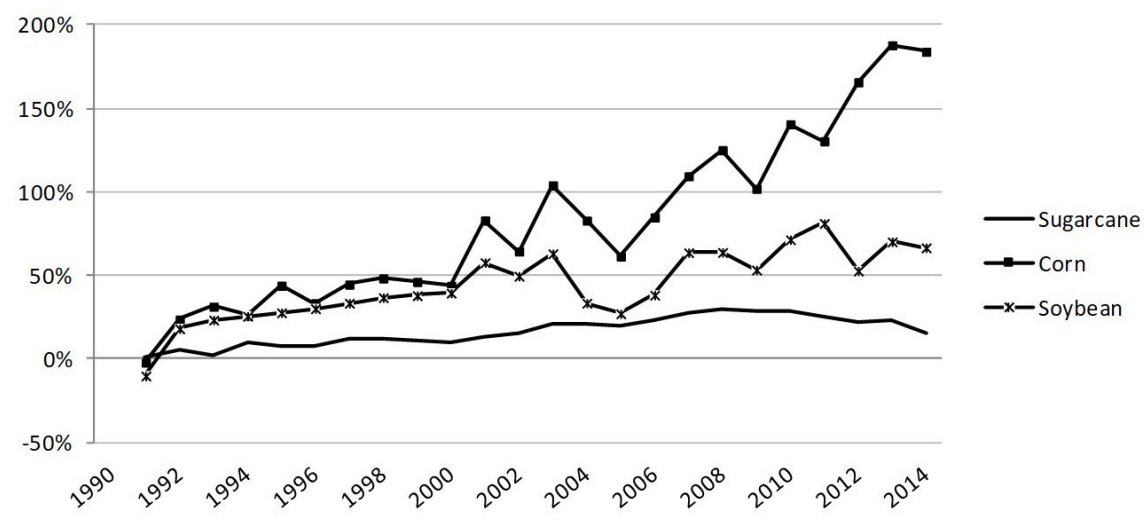

Figure 3. Productivity gains (\%), base 1990, of sugarcane, corn and soybeans in Brazil, between 1990 and 2014. Source: The authors, based on IBGE (2015). 
(2008). Under this perspective, this work used this model, adapting it to calculate the decomposition of the rate of variation of sugarcane production in the components "harvested area" and "productivity".

In order to analyze the evolution of the sugarcane crop in the studied regions, we start with the Expression 1 , which presents the agricultural production as a result of the product between the area harvested and its respective productivity:

$$
\mathbf{P}=\mathbf{A} \times \boldsymbol{\rho}
$$

being that: $\mathrm{P}=$ production of sugarcane in tons (ton); $\mathrm{A}=$ harvested area in hectares (ha); $\rho=$ productivity in tons per hectares (ton / ha).

According to the method, as a first step it is necessary measure the variation of the sugar cane production $(\mathrm{P})$ between two periods: the beginning (i) and the end (f). In this study, annual periods are adopted. Thus, Expression 2 shows the production of sugarcane in tons, in a given period " $i$ " (previous year); while Expression 3 shows sugarcane production in tones, in a given period "f" (current year):

$$
\begin{aligned}
& \mathbf{P}_{\mathrm{i}}=\mathbf{A}_{\mathrm{i}} \times \boldsymbol{\rho}_{\mathrm{i}} \\
& \mathbf{P}_{\mathrm{f}}=\mathbf{A}_{\mathrm{f}} \times \boldsymbol{\rho}_{\mathrm{f}}
\end{aligned}
$$

Next, the "production variation" of a given period is calculated, according to the "area" variable, keeping "productivity" constant, according to Expression 4:

$$
\mathbf{P}_{\mathbf{f}}^{\mathbf{A}}=\mathbf{A}_{\mathbf{f}} \times \boldsymbol{\rho}_{\mathbf{i}}
$$

In the same way, the "production variation" of a given period is calculated, according to the "productivity" variable, keeping the "area" constant, as described in Expression 5:

$$
\mathbf{P}_{\mathbf{f}}^{\rho}=\mathbf{A}_{\mathbf{i}} \times \mathbf{p}_{\mathbf{f}}
$$

Therefore, the "variation in production" (We present, as an example, the calculation of the variation of the sugarcane production in Brazil in the year 2014. The initial production $\left(\mathrm{P}_{\mathrm{i}}\right)$ is equivalent to the production of 2013, and the final production $\left(\mathrm{P}_{\mathrm{f}}\right)$ is equivalent to the 2014) of sugarcane between period "i" (previous year) and period "f" (current year) is expressed by Expression 6:

$$
\mathbf{P}_{\mathbf{f}}-\mathbf{P}_{\mathbf{i}}=\left(\mathbf{P}_{\mathbf{f}}^{\mathbf{A}}-\mathbf{P}_{\mathbf{i}}\right) \times\left(\mathbf{P}_{\mathbf{f}}-\mathbf{P}_{\mathbf{f}}^{\mathbf{A}}\right)
$$

being that: $P_{f}-P_{i}=$ total change in production, in tones; $\mathrm{P}_{\mathrm{f}}^{\mathrm{A}}-\mathrm{P}_{\mathrm{i}}=$ harvested area effect, in hectares; $\mathrm{P}_{\mathrm{f}}-\mathrm{P}_{\mathrm{f}}^{\mathrm{A}}=$ productivity effect, in tons per hectare .

The explanatory effects, in this case "area" and "productivity", can be represented in the form of annual growth rates, which together result in the annual rate of production variations (Camara \& Caldarelli, 2016).
The "area effect" is an indicator of variation in sugarcane production, resulting from the incorporation of new areas and/or crop substitution, which are related to changes in the agrarian structure (Camara \& Caldarelli, 2016; Lourenzani \& Caldas, 2014.

The "productivity effect" represents the variation in sugarcane production due to the intensification of the means of production, including the improvement of applied technology, the use of more adapted sugarcane varieties, mechanization efficiency in planting and harvesting, and increasing production per unit of area (Abdala \& Ribeiro, 2011; Nyko et al., 2013).

\section{Results and discussion}

In order to understand the influence of "area" and "productivity" factors on the evolution of sugarcane production in the regions under analysis (first specific objective), the Shift-Share quantitative analysis method was adopted. Table 2 shows the development of the calculation of the explanatory effects of the evolution of production in Brazil between 2003 and 2014.

For each year, we have the annual variation of production as a result of the sum of the contributions of the factors "area" and "productivity". Thus, factors with positive values indicate the incremental contribution to the values of sugarcane production. When the factors present negative values, one has the magnitude of the contribution for the reduction of the production of sugarcane.

According to data, Brazil presents an almost continuous incremental variation of sugarcane area, with exception in the years of 2012 and 2014. The years 2006, 2007 and 2008 increases of more than $12 \%$. The same performance is not verified when analyzing the productivity effect. For the four-year period (2006/2009) the productivity factor contributed to the increase in sugarcane production. However, for the three-year period 2010/2012, productivity presented continuous rates of decrease of this indicator. 2014 showed the worst result with a negative rate of change of $4.03 \%$. This performance was due to the negative effect of the national productivity of the order of $6.37 \%$.

A similar procedure was used to calculate the explanatory effects, area and productivity, for the annual variation of sugarcane production in the states of Goias and Mato Grosso do Sul (Table 3).

Figure 4 shows the percentage evolution of sugarcane production in the state of Goias and its explanatory effects. The variation in production was continuously positive in the period, with the highlight being the peak of expansion in 2008. The representativeness of the factor "area" in this process is graphically verified; that is, the growth of this culture was due to the incorporation of new areas. There was practically no contribution of the productivity factor in this expansion process. 
Table 2. Calculation of the "area" and "productivity" effects in the evolution of sugarcane production in Brazil between 2003 and 2014.

\begin{tabular}{|c|c|c|c|c|c|}
\hline Period & $\begin{array}{c}\text { Production } \\
\text { (ton) }\end{array}$ & $\begin{array}{c}\text { Harvested Area } \\
(h a)\end{array}$ & $\begin{array}{l}\text { Productivity } \\
\text { (ton/ha) }\end{array}$ & $P_{f}^{(A)}=A_{f} x P_{i}$ & $P_{f}^{(P)}=A_{i} x P_{f}$ \\
\hline 2002 & $364,389,416$ & $5,100,405$ & 71.44 & & \\
\hline 2003 & $396,012,158$ & $5,371,020$ & 73.73 & $383,723,026$ & $376,059,369$ \\
\hline 2004 & $415,205,835$ & $5,631,741$ & 73.73 & $415,235,450$ & $395,983,914$ \\
\hline 2005 & $422,956,646$ & $5,805,518$ & 72.85 & $428,017,721$ & $410,296,253$ \\
\hline 2006 & $477,410,655$ & $6,355,498$ & 75.12 & $463,025,025$ & $436,097,400$ \\
\hline 2007 & $549,707,314$ & $7,080,920$ & 77.63 & $531,902,717$ & $493,391,217$ \\
\hline 2008 & $645,300,182$ & $8,140,089$ & 79.27 & $631,932,921$ & $561,335,259$ \\
\hline 2009 & $691,606,147$ & $8,617,555$ & 80.26 & $683,150,984$ & $653,286,877$ \\
\hline 2010 & $717,463,793$ & $9,076,706$ & 79.04 & $728,455,538$ & $681,170,426$ \\
\hline 2011 & $734,006,059$ & $9,601,316$ & 76.45 & $758,931,334$ & $693,900,419$ \\
\hline 2012 & $721,077,287$ & $9,705,388$ & 74.30 & $741,962,206$ & $713,345,092$ \\
\hline 2013 & $768,090,444$ & $10,195,166$ & 75.34 & $757,466,125$ & $731,191,211$ \\
\hline 2014 & $736,108,487$ & $10,419,678$ & 70.65 & $785,004,884$ & $720,247,614$ \\
\hline Period & $\begin{array}{c}\text { Variation of } \\
\text { production (a) } \\
P_{f}-P_{i}\end{array}$ & $\begin{array}{c}\text { Effect } \\
\text { Productivity (c) } \\
P_{f}-P_{f}^{(A)}\end{array}$ & $\begin{array}{c}\text { Annual rate } \\
\text { of production } \\
\text { variation }(d) \\
\left(P_{f} / P_{f}\right)-1\end{array}$ & $\begin{array}{c}\text { Area effect } \\
(b / a) x d\end{array}$ & $\begin{array}{l}\text { Productivity effect } \\
\text { (c/a) } x d\end{array}$ \\
\hline 2003 & $31,622,742$ & $12,289.132$ & $8.68 \%$ & $5.31 \%$ & $3.37 \%$ \\
\hline 2004 & $19,193,677$ & $-29,615$ & $4.85 \%$ & $4.85 \%$ & $0.00 \%$ \\
\hline 2005 & $7,750,811$ & $-5,061,075$ & $1.87 \%$ & $3.09 \%$ & $-1.22 \%$ \\
\hline 2006 & $54,454,009$ & $14,385,630$ & $12.87 \%$ & $9.47 \%$ & $3.40 \%$ \\
\hline 2007 & $72,296,659$ & $17,804,597$ & $15.14 \%$ & $11.41 \%$ & $3.73 \%$ \\
\hline 2008 & $95,592,868$ & $13,367,261$ & $17.39 \%$ & $14.96 \%$ & $2.43 \%$ \\
\hline 2009 & $46,305,965$ & $8,455,163$ & $7.18 \%$ & $5.87 \%$ & $1.31 \%$ \\
\hline 2010 & $25,857,646$ & $-10,991,745$ & $3.74 \%$ & $5.33 \%$ & $-1.59 \%$ \\
\hline 2011 & $16,542,266$ & $-24,925,275$ & $2.31 \%$ & $5.78 \%$ & $-3.47 \%$ \\
\hline 2012 & $-12,928,772$ & $-20,884,919$ & $-1.76 \%$ & $1.08 \%$ & $-2.84 \%$ \\
\hline 2013 & $47,013,157$ & $10,624,319$ & $6.52 \%$ & $5.05 \%$ & $1.47 \%$ \\
\hline 2014 & $-31,981,957$ & $-48,896,397$ & $-4.16 \%$ & $2.21 \%$ & $-6.37 \%$ \\
\hline
\end{tabular}

Source: The authors, based on IBGE (2015).

Table 3. Annual variation of sugarcane production in Goias and Mato Grosso do Sul, and the decomposition of the "area effect" and "productivity effect", between 2003 and 2014.

\begin{tabular}{cccccccc}
\hline & \multicolumn{3}{c}{ GOIAS } & & & \multicolumn{2}{c}{ MATO GROSSO DO SUL } \\
\cline { 2 - 3 } & $\begin{array}{c}\text { Annual } \\
\text { Variation of } \\
\text { Production }\end{array}$ & Area Effect & $\begin{array}{c}\text { Productivity } \\
\text { Effect }\end{array}$ & & $\begin{array}{c}\text { Annual } \\
\text { Variation of } \\
\text { Production }\end{array}$ & Area Effect & $\begin{array}{c}\text { Productivity } \\
\text { Effect }\end{array}$ \\
\hline 2003 & $10.57 \%$ & $13.64 \%$ & $-3.08 \%$ & & $5.31 \%$ & $7.52 \%$ & $-2.21 \%$ \\
2004 & $8.47 \%$ & $6.96 \%$ & $1.52 \%$ & & $6.00 \%$ & $8.66 \%$ & $-2.66 \%$ \\
2005 & $11.72 \%$ & $11.49 \%$ & $0.23 \%$ & & $-0.61 \%$ & $4.45 \%$ & $-5.06 \%$ \\
2006 & $21.78 \%$ & $18.30 \%$ & $3.48 \%$ & & $26.25 \%$ & $11.65 \%$ & $14.60 \%$ \\
2007 & $17.52 \%$ & $19.53 \%$ & $-2.01 \%$ & & $31.87 \%$ & $25.42 \%$ & $6.45 \%$ \\
2008 & $47.90 \%$ & $44.28 \%$ & $3.62 \%$ & & $34.86 \%$ & $31.82 \%$ & $3.04 \%$ \\
2009 & $31.87 \%$ & $30.59 \%$ & $1.28 \%$ & & $18.10 \%$ & $13.24 \%$ & $4.85 \%$ \\
2010 & $9.92 \%$ & $10.47 \%$ & $-0.55 \%$ & & $37.92 \%$ & $39.66 \%$ & $-1.73 \%$ \\
2011 & $14.38 \%$ & $20.54 \%$ & $-6.16 \%$ & & $0.23 \%$ & $24.14 \%$ & $-23.91 \%$ \\
2012 & $6.28 \%$ & $5.06 \%$ & $1.21 \%$ & & $8.27 \%$ & $12.67 \%$ & $-4.40 \%$ \\
2013 & $18.90 \%$ & $17.41 \%$ & $1.49 \%$ & & $12.28 \%$ & $15.04 \%$ & $-2.76 \%$ \\
2014 & $1.12 \%$ & $3.99 \%$ & $-2.88 \%$ & & $3.87 \%$ & $-0.43 \%$ & $4.30 \%$ \\
\hline
\end{tabular}

Source: The authors, based on IBGE (2015). 
The percentage evolution of sugarcane production and its explanatory effects in the state of Mato Grosso do Sul is shown graphically (Figure 5). The expansion of sugarcane production was significant between the years of 2006/2010, showing high increase rates during this period. Regarding the performance of the "productivity" factor, there was a positive contribution period between 2006 and 2009, but from 2010 onwards, there was a significant decline in this factor, triggering a decrease in the quantity of sugarcane produced; only returning to positive value in 2014. Specifically, in 2011, although the increase in area reached $24.14 \%$, all this growth potential in quantity produced was annulled by the performance of $23.96 \%$ of the "productivity" factor.

According to the Sugarcane Harvest Monitoring Report (CONAB, 2011), the climate was the main cause of the fall in production of the crop in 2011. Scarce rainfall throughout the Central-West region and the occurrence of frost in Mato Grosso do Sul caused the decrease in productivity to be the highest in previous years. Still, according to the Report, other factors that reinforced the decrease in productivity were the lack of renewal of sugarcane areas, the reduction of agricultural inputs and the use of mechanization of the harvest, which accelerates the need for renewal of sugarcane areas.

Although the condition mentioned to explain the fall of 2011 are characterized as conjunctures, the trend of productivity decreases over the period of analysis in the states of Goias and Mato Grosso do Sul consists in a structural character. For Camara \& Caldarelli (2016), in order to compensate stagnation and the decrease in productivity, a less costly strategy is expand production based on extensive land use and less investments in improvements and technology was adopted. According to Nyko et al. (2013) this is characterized as a structural problem.

In this context, based on the qualitative analysis and on the arguments of Demattê et al. (2014) and Nyko et al. (2013), we have verified how the structural factors, such as the use of adequate varieties and the mechanization index, affect sugarcane productivity in the states under analysis (according to the specific objective of the work).

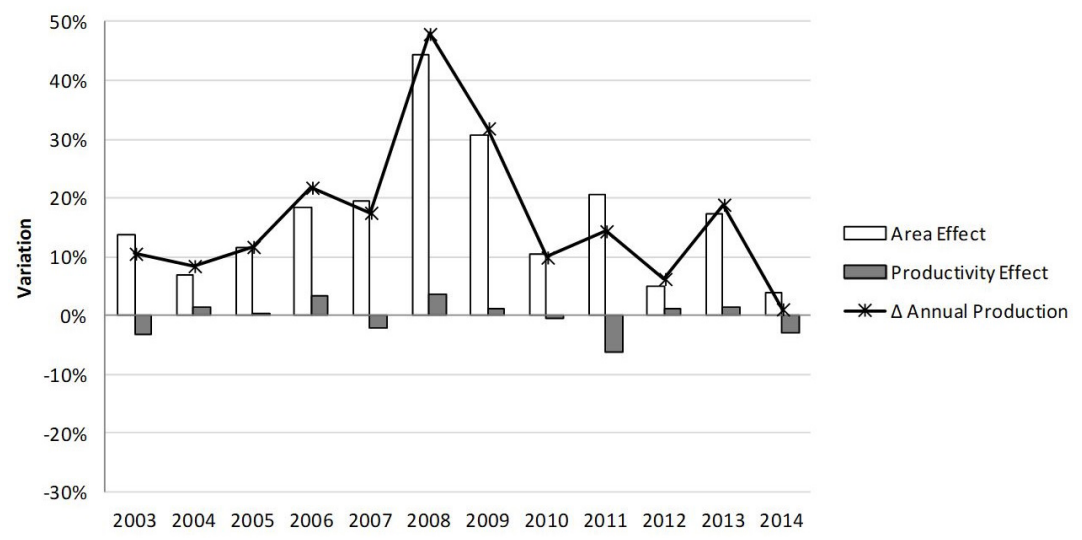

Figure 4. Variation of the production of sugarcane in the state of Goias, by the decomposition of the area effect and productivity effect, in the period from 2003 to 2014. Source: The authors, based on IBGE (2015).

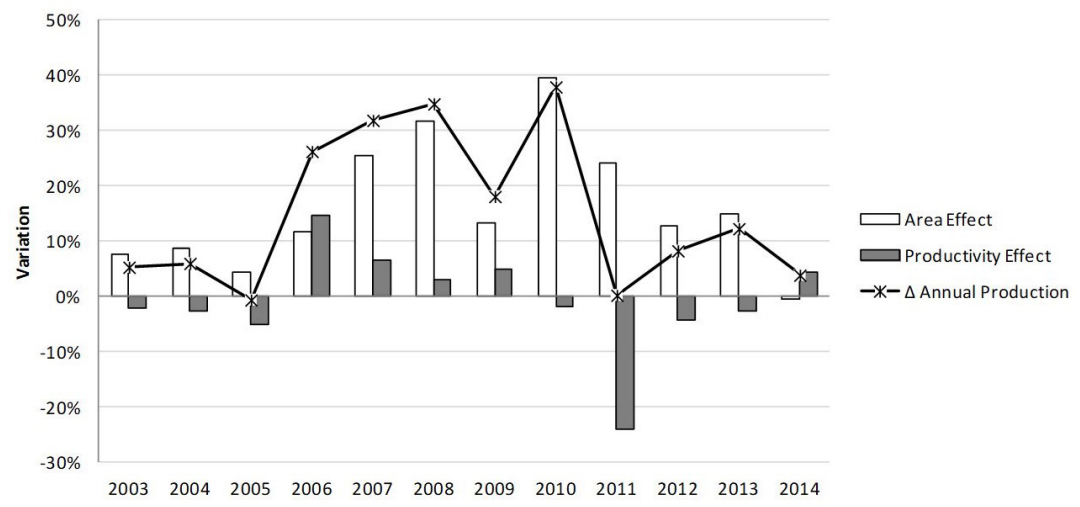

Figure 5. Variation of sugarcane production in Mato Grosso do Sul, by the decomposition of the effect area and productivity effect, from 2003 to 2014. Source: The authors, based on IBGE (2015). 
According to Santos (2016), Nyko et al. (2013) and CTC (2012), one of the alternatives to promote yield gains by area is the development and diversification of varieties, improving varietal update rates (VURs) and varietal concentration indexes (VCIs).

The VCI seeks to evaluate the degree of concentration of the main varieties in Brazilian sugarcane. This index indicates the degree of dependence of sugarcane in relation to the main varieties used and, consequently, the risks associated with this dependence. The index is calculated based on the percentage participation of the three main varieties in the region studied (CTC, 2012). VCI values above $50 \%$ are considered high and not recommended; values between 40 and $50 \%$ are considered intermediate and values lower than $40 \%$ are considered low and ideal (CTC, 2012).

The VUR is a measure of technological diffusion, that is, it evaluates the rate at which the new varieties released are adopted in Brazilian sugarcane crops. This index is obtained by the difference between the current year and the year of crossing the variety pondered by the percentage of use of each variety in the studied region. From the value obtained, 20 years period is subtracted, which correspond to the average number of years that a variety takes to reach its apex. For this index, values above seven years are considered high, between five and seven are intermediate and values below five years are considered low. Low values are desirable.

CTC (2012) report provided the data for the analysis of the use of sugarcane varieties in the producing regions of Mato Grosso do Sul and Goias (Table 4).

Despite efforts to introduce new varieties, there have been no gains in productivity parameters. It can be noticed that the preference of planting, in both states, focused on the varieties developed in the 1980s, especially RB 86-7515 and SP 81-3250, which were developed for the main producing region of that time, the state of Sao Paulo.

According to Demattê (2012), the main reasons for maintaining the varieties of the 1980s are: the increase harvest mechanization, with all the benefits from one side and productive injuries from the other; the proliferation of diseases in new varieties which have reduced their efficiency. Thus, the farmers tend to use experienced varieties.

Santos (2016) affirms that a factor that contributes to productive disparities is the great delay between the availability of varieties and their commercial adoption, which takes up to 12 years after they have been definitively approved. Table 4 indicates that for high values of VUR, over seven years (7.4 for MS and 7.8 for GO), a slower rhythm of sugarcane substitution is noticed for more modern and higher productive potential varieties. That means that the farmers of Mato Grosso do Sul and Goias are using old varieties and with lower potential level of productivity. The indicator VCI reveals the percentage of cultivated area in the states for the three main varieties in 2012. It was observed that around $50 \%$ of the cultivated area concentrates few varieties.

Regarding the adoption of the mechanization of the sugarcane planting and harvesting process, a survey by the Center for Sugarcane Technology (CTC, 2012) reveals great advances in the Central-South region of the country (Table 5).

Between 2005 and 2012, there was a total inversion in the proportionality of the use of machines for the sugarcane harvesting process. This growth demonstrates the great adherence to mechanization by the farmers, aiming at the adaptation to the Agro-Environmental Protocol (CTC, 2012). We confirm that the states of Mato Grosso do Sul and Goias had a recent process of expansion of sugarcane supported by the imperative

Table 4. Percentage (\%) of the adoption of sugarcane varieties, values of BWI (years) and IVC (\%), in Goias (GO) and Mato Grosso do Sul (MS), in 2012.

\begin{tabular}{ccccccccccc}
\hline & RB $^{1}$ & SP $^{2}$ & RB & SP & RB & RB & RB & $\begin{array}{c}\text { Other } \\
\text { varieties }\end{array}$ & $\begin{array}{c}\text { VUR } \\
\text { (years) }\end{array}$ & $\begin{array}{c}\text { VCI } \\
(\%)\end{array}$ \\
\hline GO & $(\%)$ & $\mathbf{( \% )}$ & $\mathbf{( \% )}$ & $\mathbf{( \% )}$ & $\mathbf{( \% )}$ & $\mathbf{( \% )}$ & $\mathbf{( \% )}$ & $\mathbf{( \% )}$ & & \\
MS & 24.0 & 22.0 & 5.0 & 5.0 & 3.0 & - & - & 41.0 & $\mathbf{7 . 4}$ & $\mathbf{5 1 . 0}$ \\
\hline
\end{tabular}

${ }^{1}$ RB - RIDESA variety (Interuniversity Network for the Development of the Sugar and Alcohol Sector); ${ }^{2}$-variety CTC (Sugarcane Technology Center). Source: The authors, based CTC (2012).

Table 5. Adoption (\%) of the mechanization of the harvest and planting, in the Center-South region, in Mato Grosso do Sul and Goias.

\begin{tabular}{|c|c|c|c|c|c|c|c|c|c|c|}
\hline Region & \multicolumn{8}{|c|}{ Center-South } & MS & GO \\
\hline Year & 2005 & 2006 & 2007 & 2008 & 2009 & 2010 & 2011 & 2012 & 2012 & 2012 \\
\hline Mechanical harvesting & 34.7 & 36.7 & 42.8 & 53.4 & 60.1 & 72.8 & 79.2 & 85.1 & 95.0 & 88.0 \\
\hline Manual harvesting & 65.3 & 63.3 & 57.2 & 46.6 & 39.9 & 27.2 & 20.8 & 14.9 & 5.0 & 12.0 \\
\hline Mechanical planting & & & 8.9 & 24.8 & 32.6 & 35.1 & 47.8 & 59.6 & 77.0 & 90.0 \\
\hline
\end{tabular}

Source: The authors, based CTC (2012). 
use of technology, presenting a high adherence of mechanization of planting and harvesting, superior to the national average and the state of São Paulo, the main producer state.

This practice shows positive aspects, such as the reduction of the burning of sugarcane straw (environmental and health impacts) and the reduction of manual labor (economic and social impacts). But from the other hand it has raised questions about the productive gains of this shift. Although the more favorable geographic characteristics of the states of Goias and Mato Grosso do Sul facilitated the introduction of mechanized agriculture (Sant'Anna et al., 2016), the intensive use of mechanization did not meet the expectations of productivity gains of sugarcane. According to Santos (2016), difficulties in adapting mechanized harvest were one of the technical causes of the fall in productivity in this region.

Considering as one of the structural factors that has negatively impacted the agricultural performance of this crop, the mechanization, both in planting and harvesting, has caused a reduction in performance. According to Nyko et al. (2013) and Demattê (2012), the negative results of intensive mechanization of planting and harvesting of sugarcane are: increased traffic in the cropping areas, which leads to greater soil compaction; the cut executed by the machine is higher, leaving in the soil a noble portion of the cane (much sugar is concentrated in the base of the colm); need to use more seedlings when compared to manual planting, amongst others.

\section{Conclusions}

It is evident the importance of the geographic delimitation adopted in this article. In the last decade, the states of Mato Grosso do Sul and Goias have had great relevance in the national scenario of sugarcane cultivation, becoming the main region of sugarcane agricultural expansion.

From the quantitative analysis performed through the Shift-Share method, we can affirm that the expressive process of sugarcane expansion in the regions analyzed was predominantly due to the incorporation of new planting areas. The contribution of the productivity factor was inexpressive, revealing a less costly strategy to increase the production of this crop. These results follow the studies presented by Camara \& Caldarelli (2016), Castro et al. (2010) and Nassar et al. (2008) for other periods and regions.

The potential for growth of productivity indices in sugarcane cultivation in Brazil and in the regions surveyed is evidenced. Although conjunctural factors (short term) have a direct influence on agricultural productivity, this work focused on the analysis of the structural factors (long term) of sugarcane activity, especially the use of adequate varieties and agricultural mechanization.
From a qualitative approach, the analyzes indicate a slow rhythm of renewal of sugarcane varieties in the states of Goias and Mato Grosso do Sul, as well as high concentrations in few varieties in the areas. The predominantly used varieties were developed in the 1980s. Moreover, although the adoption of technology is imperative in the regions of new sugarcane agricultural expansions, this has not proved to be efficient. The index of mechanization of sugarcane cultivation is high, both for planting and harvesting; however, the difficulty in technological adaptation still implies a deficiency in the agricultural performance of sugarcane.

Therefore, we assume that the investment in adapted varieties for the edaphoclimatic conditions of Mato Grosso do Sul and Goias, with better adaptation to the intensive systems of mechanized planting and harvesting, associated to the technological improvement of the equipment, should be the focus of the researches and of the technologies generated to guarantee an increasing rate of sugarcane productivity in Brazil.

Finally, we conclude that the results obtained in this work, by using qualitative and quantitative analysis, allow us to confirm the assumptions initially raised regarding the relevance of structural factors for the (non) evolution of sugarcane productivity in Brazil and in the regions of new agricultural expansions.

\section{References}

Abdala, K. O., \& Ribeiro, F. L. (2011). Análise dos impactos da competição pelo uso do solo no estado de Goiás durante o período 2000 a 2009 provenientes da expansão do complexo sucroalcooleiro. Revista Brasileira de Economia, 65(4), 373-400. http://dx.doi. org/10.1590/S0034-71402011000400004.

Camara, M. R. G., \& Caldarelli, C. E. (2016). Expansão canavieira e o uso da terra no estado de São Paulo. Estudos Avançados, 30(88), 93-116. http://dx.doi. org/10.1590/s0103-40142016.30880008.

Camargo, A. M. M. P., Caser, D. V., de Camargo, F. P., Olivette, M. P. A., Sachs, R. C. C., \& Torquato, S. A. (2008). Dinâmica e tendência da expansão da cana-deaçúcar sobre as demais atividades agropecuárias, Estado de São Paulo, 2001-2006. Informações Econômicas, 38(3), 47-66. Retrieved in 2015, February 22, from http:// www.iea.sp.gov.br/out/bioenergia/textos/ie-0308.pdf

Castro, S. S. D., Abdala, K., Silva, A. A., \& Bôrges, V. M. S. (2010). A expansão da cana-de-açúcar no Cerrado e no Estado de Goiás: elementos para uma análise espacial do processo. Boletim Goiano de Geografia, 30(1), 171-190. http://dx.doi.org/10.5216/bgg.v30i1.11203.

Centro de Tecnologia Canavieira - CTC. (2012). Censo varietal e de produtividade em 2012. Piracicaba. Retrieved in 2015, February 22, from http://www.ctcanavieira. com.br/downloads/Censo2012.pdf 
Companhia Nacional de Abastecimento - CONAB. (2011). Acompanhamento de safra brasileira: cana-de-açúcar, terceiro levantamento, dezembro/2011. Brasília. Retrieved in 2017, November 2, from http://www.conab.gov.br/ OlalaCMS/uploads/arquivos/11_12_08_11_00_54_08.pdf

Demattê, J. A. M., Demattê, J. L. I., Alves, E. R., Barbosa, R. N., \& Morelli, J. L. (2014). Precision agriculture for sugarcane management: a strategy applied for Brazilian conditions. Acta Scientiarum. Agronomy, 36(1), 111-117. http://dx.doi.org/10.4025/actasciagron.v36i1.17664.

Demattê, J. L. I. (2012). Variedades de cana estão devendo.... Revista RPANEWS, 11(141), 16-24.

Domingues, A. T., \& Thomaz, A., Jr. (2012). A territorialização da cana-de-açúcar no Mato Grosso do Sul. Caderno Prudentino de Geografia, 1(34), 138-160. Retrieved in 2017, November 2, from http://revista.fct.unesp.br/ index.php/cpg/article/view/459/1818

Furtado, A. T., Scandiffio, M. I. G., \& Cortez, L. A. B. (2011). The Brazilian sugarcane innovation system. Energy Policy, 39(1), 156-166. http://dx.doi.org/10.1016/j. enpol.2010.09.023.

Gilio, L., \& Moraes, M. A. F. D. (2016). Sugarcane industry's socioeconomic impact in São Paulo, Brazil: a spatial dynamic panel approach. Energy Economics, 58, 27-37. http://dx.doi.org/10.1016/j.eneco.2016.06.005.

Granco, G., Caldas, M. M., Bergtold, J. S., \& Sant'Anna, A. C. (2017). Exploring the policy and social factors fueling the expansion and shift of sugarcane production in the Brazilian Cerrado. GeoJournal, 82(1), 63-80. http://dx.doi.org/10.1007/s10708-015-9666-y.

Instituto Brasileiro de Geografia e Estatística - IBGE. (2015). Tabela 1612. Rio de Janeiro. Retrieved in 2015 September 18, from http:/www.sidra.ibge.gov.br/bda/ tabela/listabl.asp?c $=1612 \& \mathrm{z}=\mathrm{p} \& \mathrm{o}=24$

Lourenzani, W. L., \& Caldas, M. M. (2014). Land use change from the sugar cane expansion in the western region of São Paulo state, Brazil. Ciência Rural, 44(11), 19801987. http://dx.doi.org/10.1590/0103-8478cr20140186.

Nassar, A. M., Rudorff, B. F., Antoniazzi, L. B., Aguiar, D. A. D., Bacchi, M. R. P., \& Adami, M. (2008). Prospects of the sugarcane expansion in Brazil: impacts on direct and indirect land use changes. In P. Zuurbier \& J. V. Vooren (Eds.), Sugarcane ethanol: contributions to climate change mitigation and the environment (pp. 63-93). Wagenigen: Wagenigen Academic Publishers.

Neves, M. F. (2012). Setor sucroenergético: ações para revitalização. AgroANALYSIS, 32(10), 34-35. Retrieved in 2015 May 5, from http://www.agroanalysis.com. br/10/2012/agroenergia/setor-sucroenergetico-acoespara-revitalizacao

Nyko, D., Valente, M. S., Milanez, A. Y., Tanaka, A. K. R., \& Rodrigues, A. V. P. (2013). A evolução das tecnologias agrícolas do setor sucroenergético: estagnação passageira ou crise estrutural? BNDES Setorial, 37, 399-442. Retrieved in 2015 May 5, from https://www.bndes.gov. br/SiteBNDES/export/sites/default/bndes_pt/Galerias/ Arquivos/conhecimento/bnset/set3710.pdf

Oliveira, T. B. A., Selig, P. M., Barbosa, V. M., Souza Campos, L. M., Bornia, A. C., \& Oliveira, M. W. (2012). Tecnologia e custos de produção de cana-de-açúcar: um estudo de caso em uma propriedade agrícola. Latin American Journal of Business Management, 3(1), 150172. Retrieved in 2017, November 2, from http:/www. lajbm.net/index.php/journal/article/view/48

Pereira, A. D. S. (1997). O método estrutural-diferencial e suas reformulações. Revista Teoria e Evidência Econômica, 5(9), 91-103. Retrieved in 2017, November 2, from http://seer.upf.br/index.php/rtee/article/view/4772

Sant'Anna, A. C., Shanoyan, A., Bergtold, J. S., Caldas, M. M., \& Granco, G. (2016). Ethanol and sugarcane expansion in Brazil: what is fueling the ethanol industry? The International Food and Agribusiness Management Review, 19(4), 163-182. http://dx.doi.org/10.22434/ IFAMR2015.0195.

Santos, G. R. (2016). Produtividade na agroindústria canavieira: um olhar a partir da etapa agrícola. In $\mathrm{G}$. R. Santos (Ed.), Quarenta anos de etanol em larga escala no Brasil: desafios, crises e perspectivas (pp. 165-186). Brasília: IPEA.

Spera, S., VanWey, L., \& Mustard, J. (2017). The drivers of sugarcane expansion in Goias, Brazil. Land Use Policy, 6, 111-119. http://dx.doi.org/10.1016/j. landusepol.2017.03.037. 